\title{
Leaching Potential of Diuron and Linuron in Gaza Soils
}

\author{
Yasser El-Nahhal*, Mohamed Abadsa, Samir Affifi \\ Department of Environment and Earth Sciences, The Islamic University, Palestinian National Authority (PNA), \\ Gaza, Palestine \\ Email: ${ }^{*} y$ el nahhal@hotmail.com
}

Received 26 October 2014; revised 21 November 2014; accepted 5 December 2014

Copyright (C) 2014 by authors and Scientific Research Publishing Inc.

This work is licensed under the Creative Commons Attribution International License (CC BY). http://creativecommons.org/licenses/by/4.0/

(c) (i) Open Access

\section{Abstract}

This study investigated the leaching potential of diuron and linuron in different soil types in Gaza Strip, Palestine under laboratory and field conditions. Leaching potential was evaluated by tin columns and bioassay technique using Molokhia as test plant. The responses of the test plant were regressed versus concentrations of the herbicide to estimate linear regression equation and the regression coefficient. The obtained results indicate strong positive association between Molokhia and concentrations of diuron or linuron; accordingly it was used in the bioassay and estimation of the concentrations of the tested herbicides in the leaching depth. Leaching potential was very low in North Gaza and Kkan Younis soil, whereas in the Meddle zone soil was very large. Leaching potential under laboratory conditions was larger that under field conditions. The bioestimated concentrations in soil layer under field conditions were sever folds of magnitude lower than those under laboratory conditions. The interesting outcome of this study is that leaching potential is dependent on soil clay fraction, soil organic matter, and soil $\mathrm{pH}$. These results provided answers to the questions raised by farmers in Gaza Strip.

\section{Keywords}

Leaching Potential, Diuron, Linuron, Clay Fraction, Soil Organic Matter, Soil pH

\section{Introduction}

Leaching and distribution of herbicides in soil are necessary to achieve proper weed control and to suppress the growth of unwanted plants in the top soil layer $(0-10 \mathrm{~cm})$. However, movement of herbicides below the root zone may result in loss of herbicidal activity and create problems to plants in the next growth season and con-

${ }^{*}$ Corresponding author. 
tamination to ground water [1].

Number of studies from Gaza Strip [1]-[6], Europe [7]-[22] Japan [23] and the United States [24]-[27] reported ground water contamination by diuron and/or linuron.

Farmers from Gaza Strip, Palestine claimed losses of herbicidal activity of diuron or linuron and reduction of plant growth following their application. Accordingly, the authors designed this study to investigate the leaching potential of diuron and linuron in different soil types in Gaza Strip and to test the biological responses of different plants to provide answers to the farmers.

\section{Materials and Methods}

Technical diuron and linuron (purity 99\%) were purchased from Sigma Aldrich, Germany, commercial emulsifiable formulation of herbicides were purchased from Gaza. The following test plants: Beans (Phaseolus vulgaris); mulukhia (Corochorus olitorius); Cucumber (Cucumis sativus); Peas (Pisum sativum) seeds were purchased from certified agricultural products in Gaza Strip.

\subsection{Soil Sampling}

The soil samples were collected from depth of $0-30 \mathrm{~cm}$ of three agricultural locations in Gaza Governorates (Khan Younis Governorate, Middle Governorate and North Gaza Governorate). The samples were air dried, sieved through $2 \mathrm{~mm}$ mesh, transferred to a plastic bags, and storage at the lab until use. The soil properties are shown in [28].

\subsection{Leaching Potential of Diuron and Linuron}

\subsubsection{Bioassay Technique}

Following the procedure described earlier [1] and modified [29], about $40 \mathrm{mg}$ diuron or linuron were dissolved separately in one liter volumetric flask and used as stock solution to prepare the following concentrations: 0 , $0.013,0.027,0.055,0.11,0.22,0.44$, and $0.88 \mathrm{mg} / \mathrm{kg}$ soil. The soils were mixed thoroughly in polyethylene plastic bags to insure complete homogenization and even distribution of diuron or linuron in soil. To avoid losses of herbicides due to possible sorption to the polyethylene bags because of mixing, an appropriate herbicide solution was incorporated in the soil sample, followed by a manual rotary mixing using a glass rod. The treated soils were transferred to five black plastic pots. Each pots have four holes at the bottom covered by tissue paper. Ten seeds of the test plant, were placed in each pot in the lot. The following test plants: beans; Molokhia; cucumber and peas seeds were evaluated for sensitivity to diuron and linuron. Shoot height or fresh weight were determined 2 weeks after treatment, and percent growth inhibition for each test plant was calculated using Equation (1).

$$
\% \text { Growth Inhibition }=100(P c-P t) / P c
$$

where $P c$ and $P t$ are the shoot height of the control and the treated samples, respectively. The growth inhibition data were regressed versus corresponding concentrations and used to establish the regression equation. This enabled the calculation of LC50. The lowest LC50 value indicates the high sensitivity of the test plant.

The sensitive test plant was used to estimate the leaching potential of the herbicides in soil by estimating the growth inhibition or relative concentration of diuron or linuron at different soil layers using bioassay and column techniques (Figure 1).

\subsubsection{Leaching Potential of Herbicides at Laboratory Columns}

The columns were made from tin with $10 \mathrm{~cm} \times 10 \mathrm{~cm}$ surface area and $25 \mathrm{~cm}$ height. The bottom of the columns contained several micro-holes of $2 \mathrm{~mm}$ mesh. The columns were filled with 2 letter of an air-dried, sandy soil, sieved through a $2 \mathrm{~mm}$ screen. The soil surfaces were sprayed with the field rate (active ingredient $2.0 \mathrm{~kg} / \mathrm{ha}$ ) of either diuron or linuron commercial EC formulation. The columns were carefully irrigated with $500 \mathrm{~m}^{3} / \mathrm{ha}$ applied in portions over $4 \mathrm{~h}$ at $30 \mathrm{~min}$ intervals. The columns were left for $48 \mathrm{~h}$ for equilibration and sliced along their lengths, hence forming two pots. The pots were used for bioassay in the greenhouse, the test plant (Molokhia) was sown in two rows in each column half. The pots were left for 2 days without irrigation to insure absorption soil solution which may have threshold concentration of diuron or linuron due to potential leaching. The 


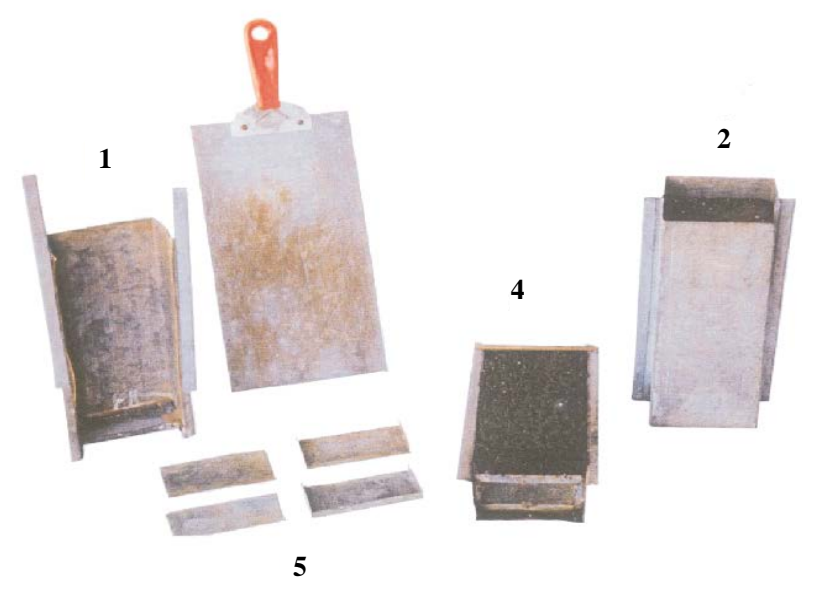

Figure 1. Columns techniques used for leaching experiments: 1 , empty half column; 2 , complete column full of soil; 3 , special spatula to divide the column; 4 , a half column ready for sowing test plants; 5, stoppers [1].

sprinkle irrigation was supplied as needed. Relative concentration of diuron or linuron could be determined at various soil layers by a reduction in tissue dry weight or height of the test plant using Equation [1] and application of a linear regression equation generated from the standard curve Equation (2).

$$
Y=a X+c
$$

$Y$ represents growth inhibition of the test plant determined by Equation (1), and $X$ represents herbicide concentration (mg/kg soil), $a$ and $c$ are the slope and the intercept of the regression line and are constants related to the experimental conditions.

\subsubsection{Leaching Behavior in the Field Plots}

In the field plots, beds $\left(1 \mathrm{~m}^{2}\right)$ were prepared using a rotary tiller. Emulsifiable concentrate of diuron or linuron at $2.0 \mathrm{~kg} / \mathrm{ha}$ active ingredient, were applied pre-emergence using a back pack motorized sprayer calibrated to discharge $300 \mathrm{~L} / \mathrm{ha}$. A sprinkler irrigation system was used to water the field plots at $500 \mathrm{~m}^{3} / \mathrm{ha}$. One soil sample was taken from each plot using the one half of the tin column (Figure 1) gently inserted to a depth of $25 \mathrm{~cm}$ and supported with a wide spatula to ensure the complete removal of the soil in the column. The soil columns were carefully transferred to the greenhouse for bioassay as described above.

\subsubsection{Influence of Various Soils on Leaching Potential}

Soil samples were collected from different 3 agricultural locations in Gaza Governorate and used for leaching potential. In this technique 3 soil columns represent an area and were sprayed with the herbicide concentrations and irrigated with the required amount of water as mentioned above.

This experiment enabled us to generate information about the possible interaction between herbicide and various soils.

\subsection{Statistical Analysis}

The growth inhibition data was analyzed for variance, and main effects and interactions was tested for significance using repeated measures ANOVA. Univariate comparisons of mean growth inhibition at different depths were performed by T-test $(\alpha=0.05)$, the statistical analysis was performed by using Microsoft Excel software.

\section{Results and Discussion}

\subsection{Soil Properties}

Properties of soil used in this study are shown in Table 1. It can be seen that $\mathrm{pH}$ values of the tested soils ranged 
between 7.32 - 8. Furthermore the EC values ranged from 1.81 - $2.63 \mathrm{dS} / \mathrm{m}$, the total organic matter range from $0.801 \%-0.254 \%$. This indicates that soil is nearly poor with organic matters. The clay fraction of soils range between $10 \%-47 \%$.

\subsection{Bioassay Studies}

Growth inhibition of the test plants are shown in Figure 2 and the corresponding linear regression equations are shown in Table 2. The presented results indicate that the test plant Molokhia, (Corochorus olitorius) is the most sensitive one among all, followed by cucumber. The data in Table 2 indicate strong positive correlation. These data agree with Safi et al. [30] who found that Molokhia was sensitive to diuron.

Accordingly Molokhia was used in this study as test plant to determine the leaching potential of herbicides in columns and field plots. Responses of Molokhia to different concentrations of diuron and linuron in different Gaza soils were linear (Data not shown). The equation and the correlation coefficient of the regression lines are shown in Table 3.

\subsection{Leaching Potential in Soil Columns of Diuron}

Leaching potential of diuron and linuron in Gaza Soils are shown in Figure 3, Figure 4. It can be seen that the leaching potential is similar in three soil type and different only in Middle Governorate soil in both cases. However, the only difference in the leaching potential is that the part of the threshold concentration of both herbicides disappeared from Middle Governorate soil and accumulated at deeper depths. Whereas in the other soils the threshold concentration remained in the top soil layer $(0-5 \mathrm{~cm})$ then considerable amount of diuron and linuron moved down to different depths. More details are obvious in Figure 3, Figure 4. Nevertheless, statistical

Table 1. Some physic-chemical properties of soils used in the study.

\begin{tabular}{|c|c|c|c|c|c|c|c|c|}
\hline Site & $\mathrm{pH}$ & $\mathrm{EC} \mathrm{dS} / \mathrm{m}$ & OM \% & TOC \% & Sand \% & Silt \% & Clay \% & Texture \\
\hline KHY Z & 8 & 1.592 & 0.762 & 0.442 & 62.5 & 17.5 & 20 & Sandy loam \\
\hline $\mathrm{MZ}$ & 7.32 & 1.813 & 0.254 & 0.147 & 87.5 & 1.25 & 11.25 & Loamy sand \\
\hline $\mathrm{NZ}$ & 7.33 & 2.36 & 0.571 & 0.331 & 60 & 12.5 & 27.5 & Clay soil \\
\hline Field exp & 7.63 & 2.044 & 0.317 & 0.184 & 85 & 5 & 10 & Loamy sand \\
\hline Clay soil & 7.36 & 2.63 & 0.801 & 0.465 & 23 & 30 & 47 & Clayey silt \\
\hline
\end{tabular}

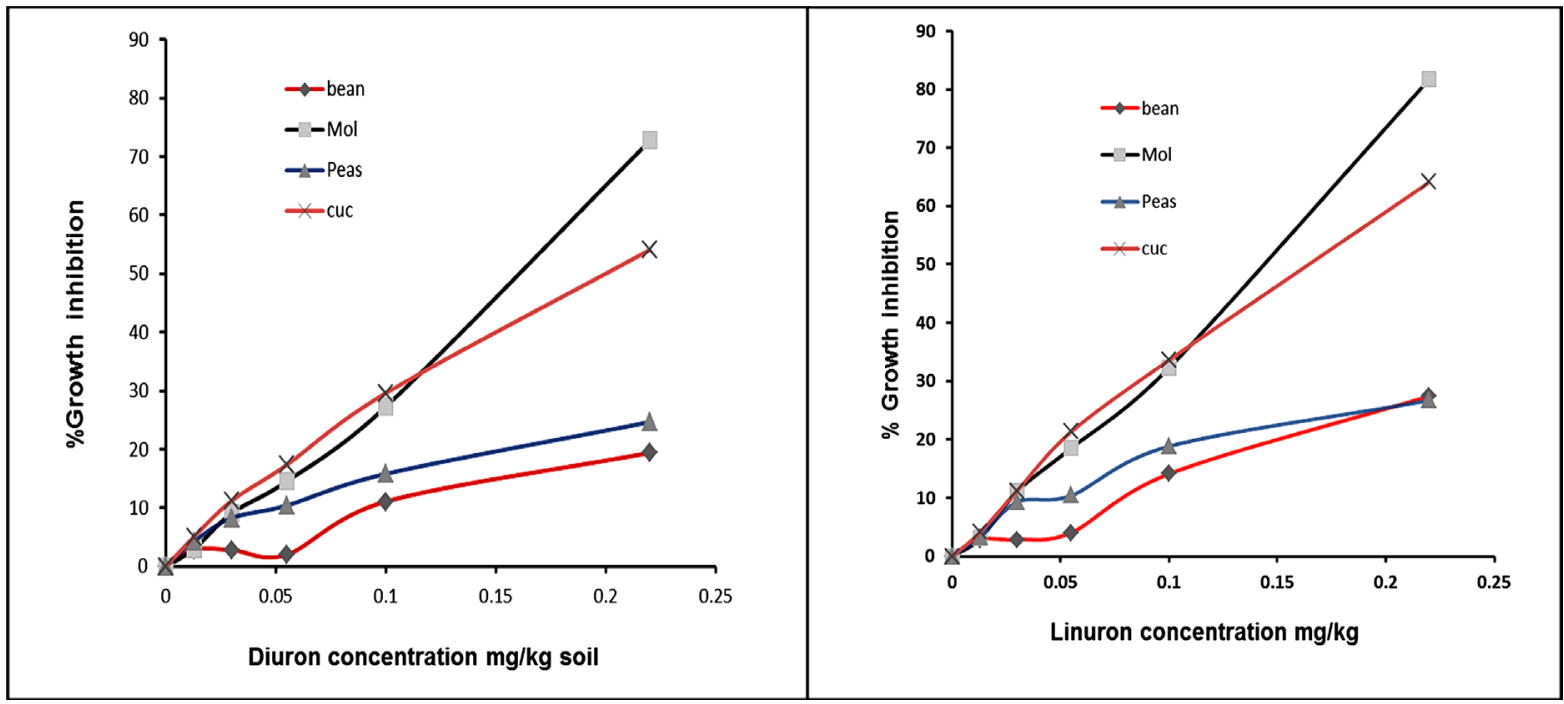

Figure 2. Effects of diuron and linuron concentrations on the growth of the test plants; bean, mul, cuc, and peas represent beans, mulukhia, cucumber and peas respectively. 
Table 2. Linear regression equation of the sensitivity plants to herbicide concentrations.

\begin{tabular}{ccc}
\hline Test plant & Equation & $R^{2}$ \\
\hline Mulukhiya & $Y=317.46 X$ & 0.9896 \\
Cucumber & $Y=259.45 X$ & 0.9762 \\
Bean & $Y=126.23 X$ & 0.8452 \\
Peas & $Y=89.812 X$ & 0.9423 \\
\hline
\end{tabular}

$Y$ and $X$ represent \% growth inhibition and concentration respectively.

Table 3. Linear regression equation and regression coefficient of diuron and linuron using Molokhia as test plant.

\begin{tabular}{ccccc}
\hline \multirow{2}{*}{ Area } & \multicolumn{2}{c}{ Diuron } & \multicolumn{2}{c}{ Linuron } \\
\cline { 2 - 5 } & Equation & $R^{2}$ & Equation & $R^{2}$ \\
\hline KHYZ & $Y=233.63 X$ & 0.95 & $Y=275.73 X$ & 0.91 \\
MZ & $Y=662.07 X$ & 0.95 & $Y=265.21 X$ & 0.98 \\
NZ & $Y=238.34 X$ & 0.93 & $Y=229.07 X$ & 0.97 \\
\hline
\end{tabular}

$Y$ and $X$ represent \% growth inhibition and concentration respectively.
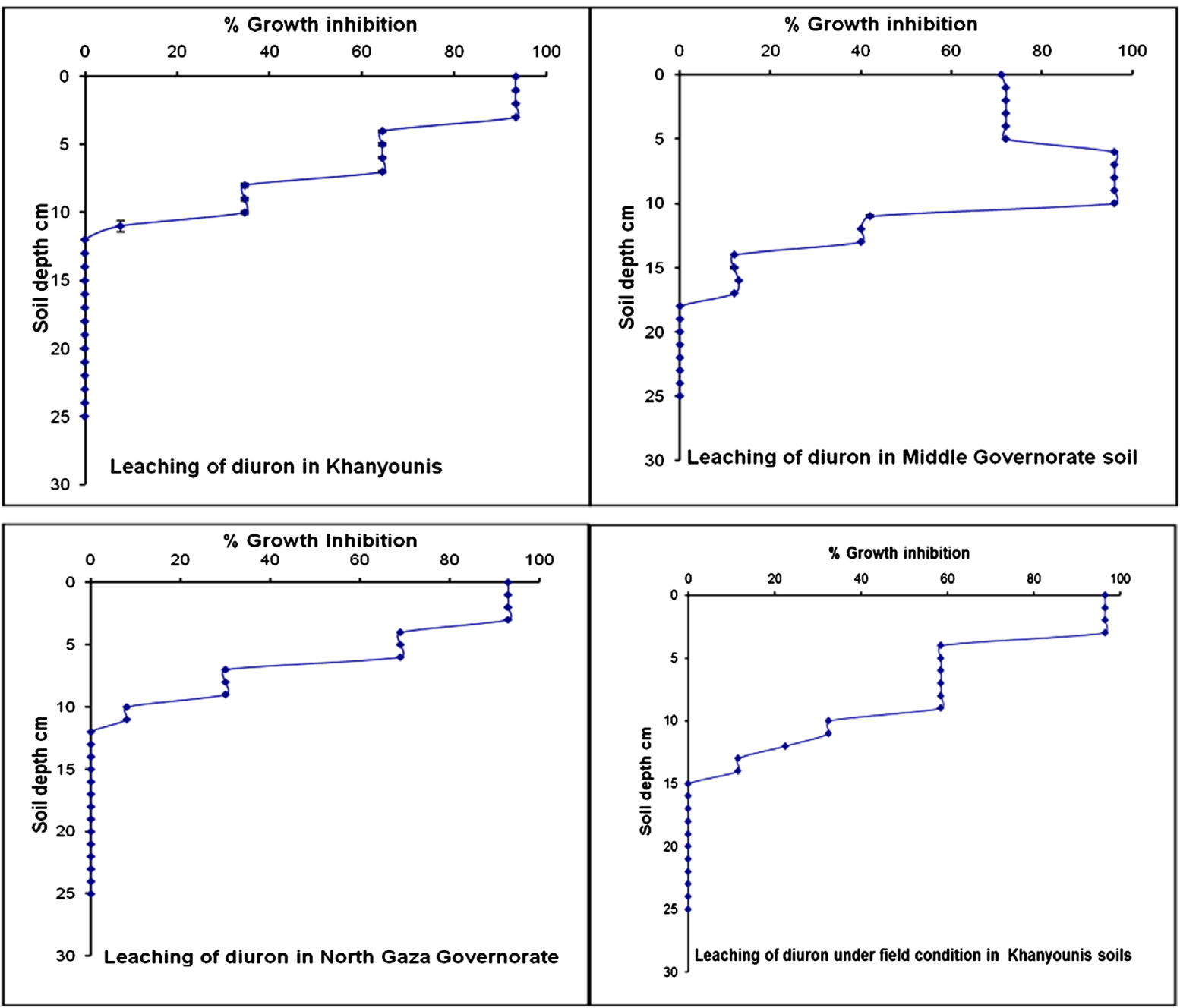

Figure 3. Leaching of diuron in different soils. Error bars represent standard deviation. Using Mulukhia as test plant. 


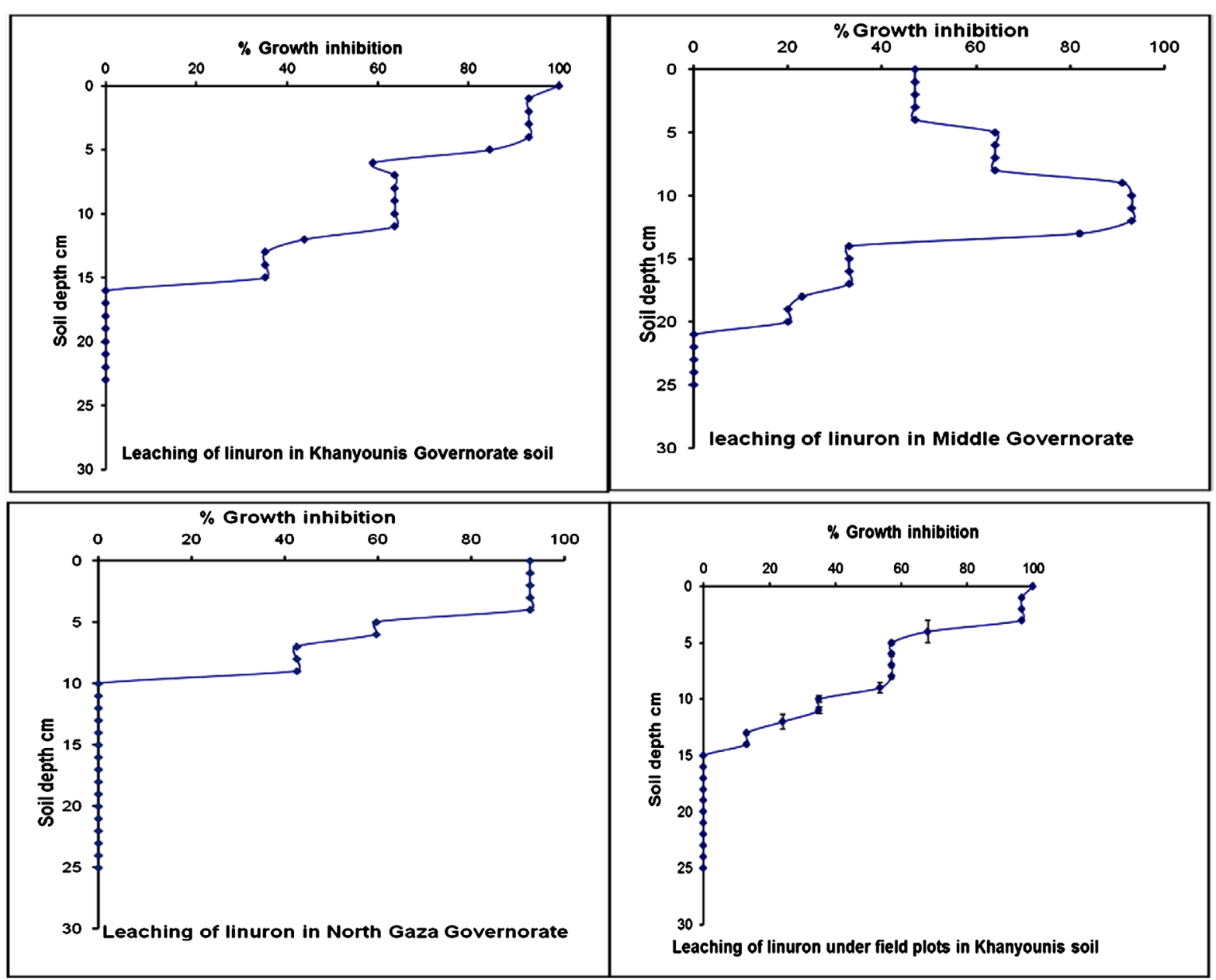

Figure 4. Leaching of linuron in different soils in Gaza Strip. Error bars represent standard deviation. Using Mulukhia as test plant.

analysis found significant difference among leaching potential. Leaching potential of diuron and linuron in the meddle Governorate were significantly different from others.

The differences in leaching potential of diuron and linuron in the tested soils are due to the differences in clay fraction, soil organic matter and soil $\mathrm{pH}$ (Table 2). Those factors affect the adsorption potential of diuron and linuron in soil [28] which affect the leaching potential in soil. These results are in agreement with previous studies which reported that diuron or linuron did not reach deeper than the $16 \mathrm{~cm}$ depth [20] [31] [32].

However, our results showed that the leached amounts of diuron or linuron were very small (Table 4), indicating a little risk of groundwater contaminating at currently field rates, moreover, the amount of used irrigation $\left(500 \mathrm{~m}^{3} / \mathrm{ha}\right)$ is not so heavy irrigation and can saturate the root zone only but at higher rate or irrigation or rainfall the potential leaching zone would become larger and pose threats to shallow ground water aquifer. Our results agree with previous that studies showed groundwater contamination by diuron or linuron in other countries [19] [20]. In different study [33] diuron and linuron were detected at depths of 20 and $40 \mathrm{~cm}$.

However, from bioestimation of the remaining concentrations at laboratory conditions, one can be concluded that leaching potential of diuron and/or linuron was the lowest in North Gaza soil followed by Khan Younis soil, the larger leaching zone was observed in Meddle zone soil (Table 4). Moreover, the remaining concentrations in the top soil layer $(0-5 \mathrm{~cm})$ reached about $0.36 \pm 0.02 \mathrm{mg} / \mathrm{kg}$ soil in North and Khan Younis soil. This concentration may reduce the growth of the plants in the next growing season as claimed by the farmers. In addition, the concentrations of Meddle zone were also high in both soil layers (0 - 5) and (6 - 10). This is also in accord with claim of the farmers in Gaza. The potential solution to this problem is to use lower applied rate of diuron and linuron for weed control. 
However, the leaching potential of both herbicides at Meddle zone soil are the largest among all soils, under this condition of leaching potential, phytotoxicity may occur to a deep rooted plants that may grow in the next growing season. Nevertheless, diuron and linuron can be classified with high potential leaching in soil profile in MZ soil. The greater mobility of diuron and linuron in to the soil columns might be due to its lower adsorption. Furthermore the adsorption results in MZ soil was the lowest among all soil [28], whereas the increase in sand content in Middle Governorate soil let diuron move easily. APVMA [34], reported that diuron moved into the soil more than $17 \mathrm{~cm}$ in sandy soil. In addition, the clay fraction in KHYZ soil is nearly 2 times higher than MZ soil (Table 1). Similar results were previously shown the clay fraction in soil has greater effect in reducing the leaching potential of herbicides [35].

\subsection{Leaching Potential of Diuron and Linuron in Field Plots}

Leaching potential of diuron and linuron under field conditions is shown in Figure 5. The presented results clearly show the herbicidal activity of both herbicides are restricted in the top soil layer $(0-4 \mathrm{~cm})$, followed by moderate growth inhibition restricted to deeper layers $(5-10 \mathrm{~cm})$, then low herbicidal activity in the layer (10 $15 \mathrm{~cm})$. Normal growth of test plant is observed in the layer $(15-25 \mathrm{~cm})$, these data indicate that diuron or linuron did not leach to this depth. The explanation of this mobility is similar to that under laboratory conditions. However, comparing the leaching depth under laboratory and field condition, one can realize that the leaching depth under field condition is lower than under laboratory condition. The explanation of these results is that under field condition herbicide moves in horizontal and perpendicular directions due to large surface area whereas

Table 4. Remaining concentration (mg/kg soil) determined by bioassay using Mulukhia as test plant.

\begin{tabular}{ccccccccc}
\hline \multirow{2}{*}{ Soil depth cm } & \multicolumn{2}{c}{ North Gaza } & \multicolumn{2}{c}{ Meddle zone } & \multicolumn{2}{c}{ Kh $Y$} & \multicolumn{2}{c}{ Kh $Y$ field exp } \\
\cline { 2 - 9 } & Diuron & Linuron & Diuron & Linuron & Diuron & Linuron & Diuron & Linuron \\
\hline $0-5$ & $0.36 \pm 0.02$ & $0.38 \pm 0.06$ & $0.12 \pm 0.03$ & $0.18 \pm 0.00$ & $0.36 \pm 0.06$ & $0.34 \pm 0.01$ & $0.13 \pm 0.00$ & $0.11 \pm 0.03$ \\
$6-10$ & $0.14 \pm 0.03$ & $0.16 \pm 0.11$ & $0.16 \pm 0.05$ & $0.28 \pm 0.05$ & $0.20 \pm 0.07$ & $0.23 \pm 0.00$ & $0.10 \pm 0.03$ & $0.06 \pm 0.02$ \\
$11-15$ & $0.03 \pm 0.00$ & BD & $0.04 \pm 0.05$ & $0.23 \pm 0.12$ & $0.06 \pm 0.08$ & $0.15 \pm 0.04$ & $0.04 \pm 0.03$ & $0.01 \pm 0.01$ \\
$16-20$ & BD & BD & $0.01 \pm 0.00$ & $0.08 \pm 0.05$ & BD & BD & BD & BD \\
$21-30$ & BD & BD & BD & BD & BD & BD & BD & BD \\
\hline
\end{tabular}

Average \pm standard deviation. Note: $\mathrm{BD}=$ below detection limit, average \pm standard deviation.

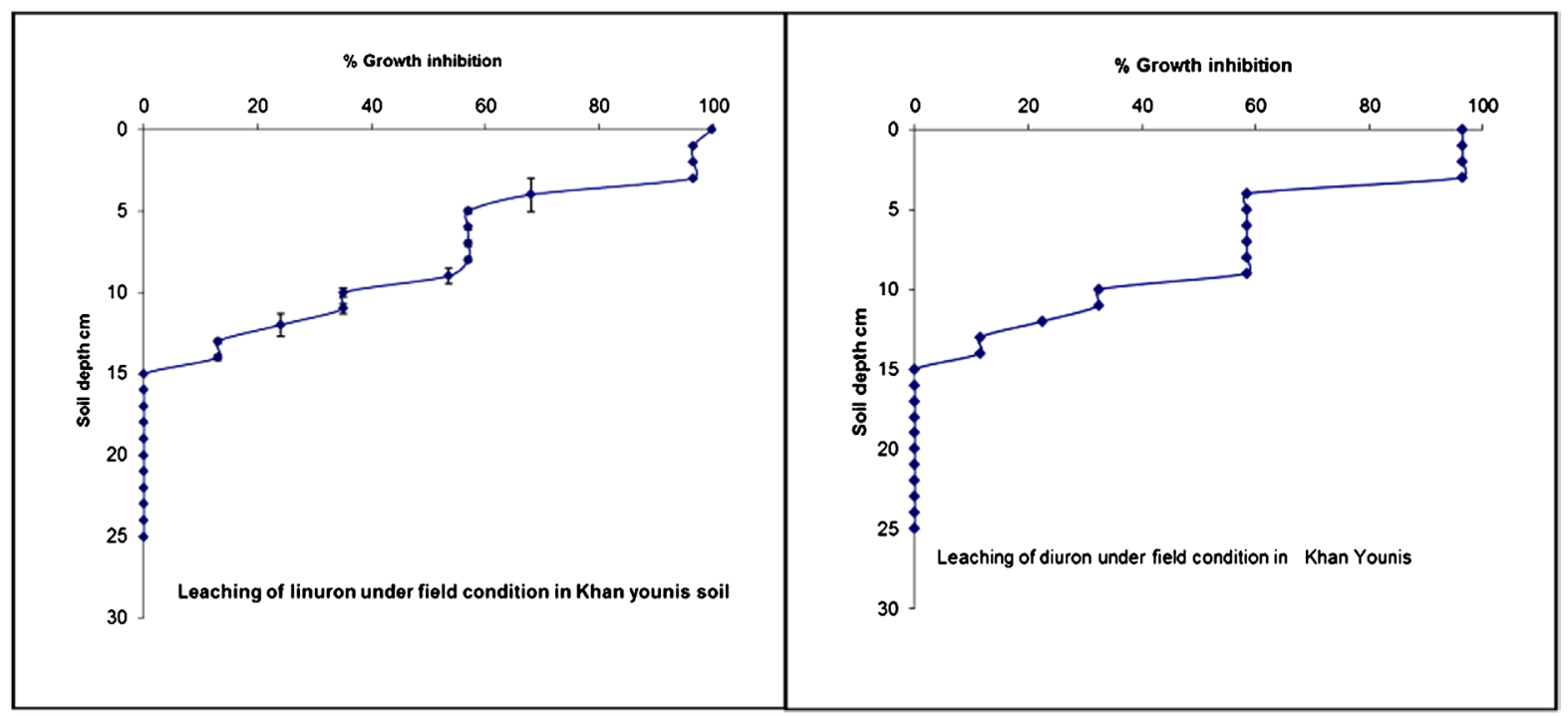

Figure 5. Leaching of linuron and diuron under field conditions in Khan Younis soils. Error bars represent standard deviation. Using Mulukhia as test plant. 
under laboratory condition, mobility is restricted to downward movement due to narrow soil surface. In addition, under filed condition, due to evaporation and high temperature in summer time upward movement may occur. Accordingly the leaching zone under field condition is smaller than under laboratory. This explanation was previously used to explain similar phenomena [1]. Bio-estimation of the concentrations of diuron and linuron under filed condition in Kh $Y$ field exp showed that the leaching potential were in the top $5 \mathrm{~cm}$ with considerable concentration whereas below this depth nearly low concentration was observed. Comparison between field and laboratory bio-estimation (Table 4) one can realize that the bioestimated concentrations under field conditions is several times lower that under laboratory conditions. The explanation of these results is that under field condition some evaporation and/or photochemical degradation may occur. The explanation is supported by previous results [35] [36].

\section{Conclusions}

This study describes the leaching potential of linuron and diuron in selected soil from Gaza Strip and provides information on the distribution of diuron and linuron concentrations in soil profile. Consequently, the study advances our understanding about the losses of herbicidal activity of the tested herbicides under field conditions; and provides answers to the questions raised by farmers in Gaza. Regardless of the similarity in some points, the leaching potential of both herbicides in Gaza soils varies from one soil to another and considerably is affected by three factors:

1) Clay fraction which is negatively charged can influence the adsorption of herbicides.

2) Soil $\mathrm{pH}$ affects the solubility of herbicides in soil solution.

3) Organic matter which acts as a non-polar phase or surface and consequently is the major sorbent for organic herbicides.

The leaching potential of both herbicides in the selected soils was strongly retained in the top soil layers except in the Middle Governorate soil. The interesting results of this study are both herbicides loss considerable concentration under field conditions. The rational of this work comes from the fact that soil $\mathrm{pH}$ and organic matter have strongly effluences in adsorption and mobility. Field experiments demonstrated less leaching potential than that in the lab experiments.

\section{Acknowledgements}

Dr. Y. El-Nahhal acknowledges Alexander von Humboldt Stiftung Foundation Fellowship Grant no IV-PAL/ 1104842 STP, Germany. Special thanks go to Prof. Dr. G. Lagaly at Kiel University, Prof. Shourrmman Germany.

\section{References}

[1] El-Nahhal, Y., Nir, S., Polubesova, T., Margulies, L. and Rubin, B. (1998) Leaching, Phytotoxicity and Weed Control of New Formulations of Alachlor. Journal of Agricultural Food Chemistry, 46, 3305-3313. http://dx.doi.org/10.1021/jf971062k

[2] El-Nahhal, Y. (2004) Contamination and Safety Status of Plant Food in Arab Countries. Applied Science, 4, $411-417$. http://dx.doi.org/10.3923/jas.2004.411.417

[3] PCBS Palestinian Central Bureau of Statistics (2009) Household Environmental Survey, Marine Finding.

[4] Safi, J.M., El-Nahhal, Y., Soliman, S.A. and El-Sebae, A.H. (1993) Mutagenic and Carcinogenic Pesticides Used in the Agricultural Environment of Gaza Strip. The Science of the Total Environment, 132, 371-380. http://dx.doi.org/10.1016/0048-9697(93)90145-V

[5] Shomar, B., Yahya, A. and Müller, G. (2006) Occurrence of Pesticides in the Groundwater and the Topsoil of the Gaza Strip. Water Air Soil Pollution, 171, 237-251. http://dx.doi.org/10.1007/s11270-005-9038-1

[6] Afifi, S., Alslaibi, T.M. and Moghaier, Y.K. (2011) Assessment of Groundwater Quality Due to the Municipal Solid Waste Landfill Leachate. Environmental Science and Technology Journal, 3, 419-436.

[7] Bauer, E.S., Meyer, H.D., Stahlschmidt-Allner, P. and Sauerwein, H. (1998) Application of an Androgen Receptor Assay for the Characterisation of the Androgenic or Antiandrogenic Activity of Various Phenylurea Herbicides and Their Derivatives. Analyst, 123, 2485-2487.

[8] Thurman, E.M., Goolsby, D.A., Aga, D.S., Pomes, M.L. and Meyer, M.T. (1996) Occurrence of Alachlor and Its Sulfonated Metabolite in Rivers and Reservoirs of the Midwestern United States: The Importance of Sulfonation in the 
Transport of Chloroacetanilide Herbicides. Environmental Science Technology, 30, 569-574. http://dx.doi.org/10.1021/es950341q

[9] Ritter, W.F., Chirnside, A.M. and Scarborough, R.W. (1996) Movement and Degradation of Triazines, Alachlor, and Metolachlor in Sandy Soils. Environmental Science and Health, Part A, 31, 2699-2721

[10] Sannino, A. (1998) Determination of Phenylurea Herbicide Residues in Vegetables by Liquid Chromatography after Gel Permeation Chromatography and Florisil Cartridge Cleanup. AOAC International, 81, 1048-1053.

[11] Caux, P.Y., Kent, R.A., Fan, G.T. and Grande, C. (1998) Canadian Water Guidelines for Linuron. Environmental Toxicology and Water Quality, 13, 1-41. http://dx.doi.org/10.1002/(SICI)1098-2256(1998)13:1<1::AID-TOX1>3.0.CO;2-B

[12] Boxall, A.B.A., Comber, S.D., Conrad, A.U., Howcroft, J. and Zaman, N. (2000) Inputs, Monitoring and Fate Modelling of Antifouling Biocides in UK Estuaries. Marine Pollution Bulletin, 40, 898-905. http://dx.doi.org/10.1016/S0025-326X(00)00021-7

[13] Ferrer, I. and Barcelo, D. (1999) Simultaneous Determination of Antifouling Herbicides in Marina Water Samples by On-Line Solid-Phase Extraction Followed by Liquid Chromatography-Mass Spectroscopy. Chromatography A, 854, 197-206. http://dx.doi.org/10.1016/S0021-9673(99)00506-3

[14] Martinez, K., Ferrer, I. and Barcelo, D. (2000) Part-per-Trillion Level Determinations of Antifouling Pesticides and Their Byproducts in Seawater Samples by Solid-Phase Extraction Followed by High-Perfomance Liquid Chromatography Atmospheric Pressure Chemical Ionization Mass Spectrometry. Chromatography A, 879, 27-37. http://dx.doi.org/10.1016/S0021-9673(00)00307-1

[15] Lamoree, M.H., Swart, C.P., van der Horst, A. and van Hattum, B. (2002) Determination of Diuron and the Antifouling Paint Biocide Irgarol 1051 in Dutch Marinas and Coastal Waters. Chromatography A, 970, 183-190. http://dx.doi.org/10.1016/S0021-9673(02)00878-6

[16] Dahl, B. and Blanck, H. (1996) Toxic Effects of the Antifouling Agent Irgarol 1051 on Periphyton Communities in Coastal Water Microcosms. Marine Pollution Bulletin, 32, 342-350. http://dx.doi.org/10.1016/0025-326X(96)84828-4

[17] Tauler, R., de Azevedo, D.A., Lacorte, S., Cespedes, R., Viana, P. and Barcelo, D. (2001) Organic Pollutants in Surface Waters from Portugal Using Chemometric Interpretation. Environmental Technology, 9, 1043-1054. http://dx.doi.org/10.1080/09593332208618211

[18] de Almeida Azevedo, D., Lacorte, S., Vinhas, T., Viana, P. and Barcelo, D. (2000) Monitoring of Priority Pesticides and Other Organic Pollutants in River Water from Portugal by Gas Chromatography-Mass Spectrometry and Liquid Chromatography-Atmospheric Pressure Chemical Ionization Mass Spectrometry. Chromatography A, 879, 13-26. http://dx.doi.org/10.1016/S0021-9673(00)00372-1

[19] Giacomazzi, S. and Cochet, N. (2004) Environmental Impact of Diuron Transformation: A Review. Chemosphere, 56, 1021-1032. http://dx.doi.org/10.1016/j.chemosphere.2004.04.061

[20] Lapworth, D.J. and Gooddy, D.C. (2006) Source and Persistence of Pesticides in a Semiconfined Chalk Aquifer of Southeast England. Environmental Pollution, 144, 1031-1044. http://dx.doi.org/10.1016/j.envpol.2005.12.055

[21] El Imache, A., Dahchour, A., Elamrani, B., Dousset, S., Pozzonni, F. and Guzzella, L. (2009) Leaching of Diuron, Linuron and Their Main Metabolites in Undisturbed Field Lysimeters. Environmental Science and Health, Part B, 44, 31-37.

[22] Sørensen, S.R., Simonsen, A. and Aamand, J. (2009) Constitutive Mineralization of Low Concentrations of the Herbicide Linuron by a Variovorax sp. Strain. FEMS Microbiology Letters, 292, 291-296.

[23] Okamura, H., Aoyama, I., Ono, Y. and Nishida, T. (2003) Antifouling Herbicides in the Coastal Waters of Western Japan. Marine Pollution Bulletin, 47, 59-67. http://dx.doi.org/10.1016/S0025-326X(02)00418-6

[24] Smith, C.N., Payne, W.R., Pope, J.D., Winkie, J.H. and Parrish, R.S. (1999) Residues and Transfer of Triazine Herbicides in Ground Waters of Intensively Exploited Arable Land in Wielkopolska Province of Poland. Chemosphere, 38, 875-889. http://dx.doi.org/10.1016/S0045-6535(98)00226-4

[25] Sapozhnikova, Y., Wirth, E., Schiff, K., Brown, J. and Fulton, M. (2007) Antifouling Pesticides in the Coastal Waters of Southern California. Marine Pollution Bulletin, 54, 1962-1989. http://dx.doi.org/10.1016/j.marpolbul.2007.09.026

[26] Wang, W. and Freemark, K. (1995) The Use of Plants for Environmental Monitoring and Assessment. Ecotoxicology Environment, 30, 289-301. http://dx.doi.org/10.1006/eesa.1995.1033

[27] DaSilva, A., Garretson, C., Troiano, J., Ritenour, G. and Krauter, C. (2003) Relating Simazine Performance to Irrigation Management. Weed Technology, 17, 330-337. http://dx.doi.org/10.1614/0890-037X(2003)017[0330:RSPTIM]2.0.CO;2

[28] El-Nahhal, Y., Abadsa, M. and Affifi, S. (2013) Adsorption of Diuron and Linuron in Gaza Soils. American Journal of 
Analytical Chemistry, 4, 94-99. http://dx.doi.org/10.4236/ajac.2013.47A013

[29] El-Nahhal, Y., Lagaly, G. and Rabinovitz, O. (2005) Organo-Clay Formulations of Acetochlor: Effect of High Salt. Journal of Agricultural and Food Chemistry, 53, 1620-1624. http://dx.doi.org/10.1021/jf040383a

[30] Safi, J., Awad, Y. and El-Nahhal, Y. (2014) Bioremediation of Diuron in Soil and by Cyanobacterial Mat. American Journal of Plant Sciences, 5, 1081-1089. http://dx.doi.org/10.4236/ajps.2014.58120

[31] Bergström, L.F., Bramble Jr., F.Q., Aronsson, P., Brücher, J. and Norwood, G.I. (1996) Leaching of [Phenyl(U)14C]Diuron in Scandinavian Soils Using Field Lysimeters. DuPont Report No. AMR 4584, Swedish University of Agricultural Sciences and E. I. du Pont de Nemours \& Co Inc, Wilmington.

[32] Futch, S.H. and Singh, M. (1999) Herbicide Mobility Using Soil Leaching Columns. Bulletin of Environmental and Contaminant Toxicology, 62, 520-529. http://dx.doi.org/10.1007/s001289900907

[33] Guzzella, L., Capri, E., Di Corcia, A., Caracciolo, A.B. and Giuliano, G. (2006) Fate of Diuron and Linuron in a Field Lysimeters Experiment. Environmental Quality, 35, 312-323. http://dx.doi.org/10.2134/jeq2004.0025

[34] APVMA, Australian Pesticides and Veterinary Medicines Authority (2011) Diuron Environment Assessment. Annual Report.

[35] El-Nahhal, Y., Nir, S., Margulies, L. and Rubin, B. (1999) Reduction of Photodegradation and Volatilization of Herbicides in Organo-Clay Formulations. Applied Clay Science, 14, 105-119. http://dx.doi.org/10.1016/S0169-1317(98)00053-2

[36] El-Nahhal, Y., Undabeytia, T., Polubesova, T., Mishael, Y.G., Nir, S. and Rubin, B. (2001) Organo-Clay Formulations of Pesticides: Reduced Leaching and Photodegradation. Applied Clay Science, 18, 309-326. http://dx.doi.org/10.1016/S0169-1317(01)00028-X 
Scientific Research Publishing (SCIRP) is one of the largest Open Access journal publishers. It is currently publishing more than 200 open access, online, peer-reviewed journals covering a wide range of academic disciplines. SCIRP serves the worldwide academic communities and contributes to the progress and application of science with its publication.

Other selected journals from SCIRP are listed as below. Submit your manuscript to us via either submit@scirp.org or Online Submission Portal.
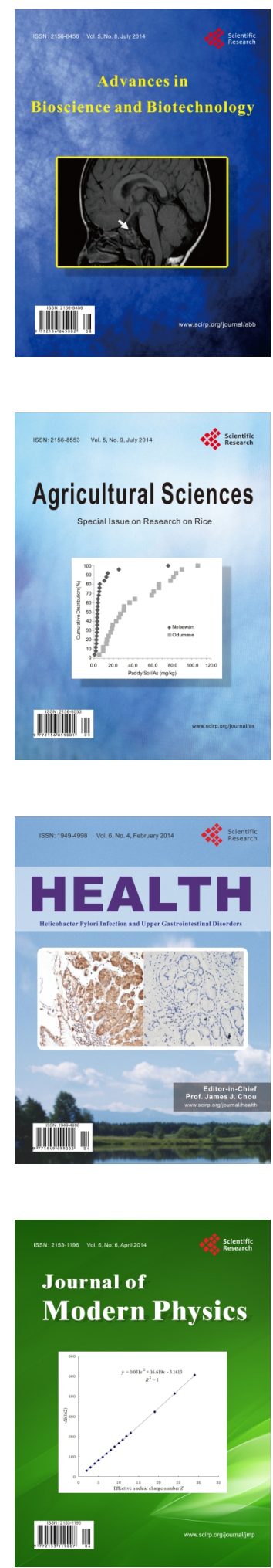
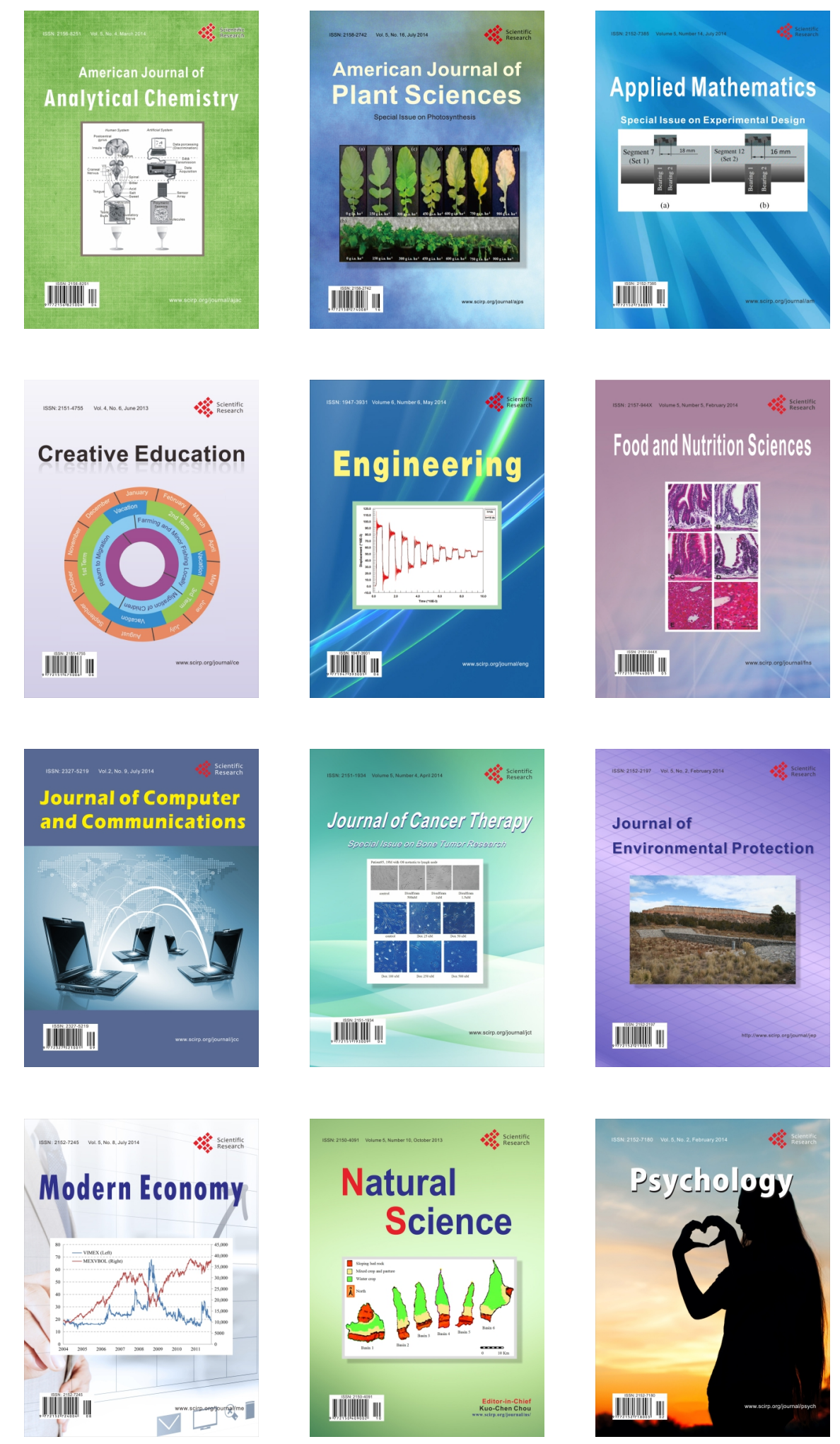